Session TA4-2

\title{
Sustainable Green Features of Bank of America Tower, NY
}

\author{
Arvind Krishna Guduri \\ Bharath Devineni \\ Ramakrishna Manchikatla \\ Civil Engineering Department \\ Lamar University \\ Professor Enno “Ed” Koehn \\ Civil Engineering Department \\ Lamar University
}

\begin{abstract}
Environmental friendly construction has been a buzz word in recent years. Construction of these buildings is graded by the U.S. Green Building Council's Leadership in Energy and Environmental Design (LEED). It has been difficult for high-rise buildings to earn a platinumlevel certification from LEED. In this paper, an example of an environmental friendly high-rise building designed to be awarded with a platinum LEED certification is taken under consideration.

The Bank of America Tower at One Bryant Park in New York City is a \$1 billion skyscraper project currently undergoing construction. It is 54 stories high and will have approximately 2.1 million square feet $\left(195,000 \mathrm{~m}^{2}\right)$ of office space. It is the first skyscraper designed to attain a Platinum LEED Certification. Therefore, a very high percentage of the building's materials will come from recycled and renewable sources within 500 miles of New York City.

The building's lead architect and mechanical engineer joined forces to give context to this skyscraper's ultra-sustainable features. Their goal is to create the world's most "environmentally responsible" high-rise office building. The main purpose of this paper is to explain some of the intriguing eco-friendly features of this high-rise structure.
\end{abstract}

\section{Introduction}

The increase in urban density has changed the need for space in urban areas. For example, in many cities in the U.S., the skyline consists of skyscrapers. For an office use, it is often more economical to build a skyscraper than a low rise building. Besides having many advantages these high-rise structures have disadvantages, like their impact on the environment and surroundings.

It is not possible to keep the negative effects of a structure to zero, but they can be reduced significantly to make cities a better place to live. One Bryant Park in New York City also known

Proceedings of 2009 ASEE Gulf-Southwest Annual Conference

Baylor University

Copyright (C2009, American Society for Engineering Education 
as the Bank of America Tower ${ }^{1,2,3,5}$, is a perfect example of this kind of structure. This paper describes the environment friendly features ${ }^{4,6,7,8,9,10}$, of this outstanding facility, which not only reduces its operating cost, but also makes it the most sustainable building.

\section{About Bank of America Tower}

\section{a) Location}

The Bank of America Tower, as shown in Figure $1^{1}$, is undergoing construction on the west side of Sixth Avenue, between 42nd and 43rd Street, opposite Bryant Park in Midtown Manhattan, New York City ${ }^{1,5}$.

b) Companies Involved

Architects:

Designing firm:

Contractor:

Developer:
Cook+Fox Architects (Exterior) $)^{2,3,5}$

Gensler (Interior) ${ }^{5,9}$

Severud Associates ${ }^{5}$

Tishman Construction Corporation ${ }^{5}$

Durst Organization, Bank of America ${ }^{5}$

\section{c) Structural Details}

According to the design,

- The Bank of America tower is $1200 \mathrm{ft}(366 \mathrm{~m})$ high at the tip of the architectural spire $^{1,5}$.

- It contains 54 stories and will have approximately 2.1 million square feet $\left(195,000 \mathrm{~m}^{2}\right)$ of office space ${ }^{5}$.

- The building will have three escalators and a total of 53 elevators - 52 to serve the offices and one leading to the transit mezzanine below ground ${ }^{1,5}$.

\section{d) Design Highlights}

- Crystalline skyscraper.

- Crystal rises from its base with sculptural facets that infer movement and allow for varied views around the neighboring towers.

- The faceted crystal design is complemented by both the clear glass curtain wall and the tautness of the skin's detail.

Crisp folds and precise vertical lines are animated by the movement of the sun .

- The south-facing facet turns to address its prominent relationship with Bryant $\operatorname{Park}^{1,5,10}$.

\section{e) Tallest Buildings in New York}




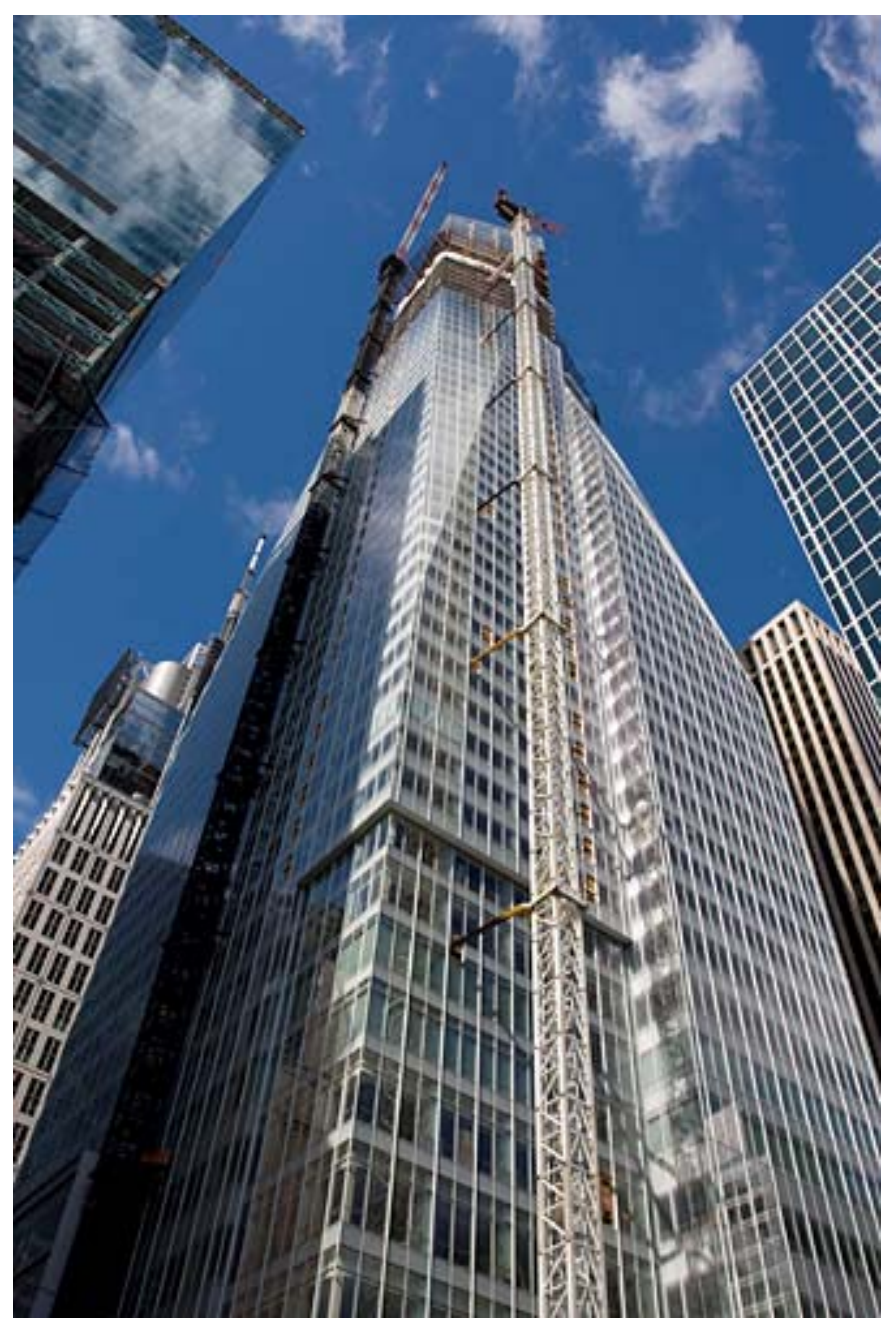

Figure 1.

The Bank of America Tower under construction on 12 October $2007^{1}$. 
As compared to the tallest buildings in New York City, Bank of America Tower is the second tallest, just $50 \mathrm{ft}(15 \mathrm{~m})$ short of the city's current record holder, the Empire State Building, as shown in Figure $2^{1}$. Yet it will have only 54 stories far fewer than one might expect for such a tall building. (The Empire State Building, by comparison, has 102 stories.) The reasons are directly related to the environmental goals of the project ${ }^{1,5,9}$.

\section{Sustainable Green Features}

The Bank of America tower will be the country's greenest skyscraper, demonstrating the state of the art in energy efficiency, indoor air quality, sustainable materials, environmentalfriendly construction and operations. The following describes the sustainable green features which are planned and designed for attaining platinum level certification ${ }^{1,2,3,4,6,7,8,9,10}$.

\section{Water Utilization}

Nearly 48 inches of rain fall on New York City every year. At the Bank of America Tower, barely a drop of this will find its way into the city's overburdened storm-water system. Instead, the tower funnels and collects precipitation that lands on its upward slant and its top-floor green roofed atrium and ends up in four holding tanks. These are positioned throughout the building's core at various levels to minimize the need to pump water up and down ${ }^{7,8,10}$.

Even water in the air is harvested by collecting condensation that drips from air conditioning cooling coils. The rainwater reservoir is used to feed the A/C system, toilets, and irrigate plants. Not even the steady, if small, flow of groundwater that seeps in through the bedrock in the tower's deepest basement levels is wasted. Before being added to rainwater storage this cool groundwater is run through a heat exchanger to assist the $\mathrm{A} / \mathrm{C}$ system $^{7,8,10}$.

The tower's most noticeable water-saving trick may be found in the men's room. Falcon Waterfree's flushless urinals are made of a super-slick material that resists bacterial buildup and lets urine bead off and roll down into the drain. Urine pours into the clever U-shaped tank filled with a blue glycerin-based liquid that, like oil on water, floats on top, sealing off odors. The urine settles to the bottom to be drained out to the sewer system. It's a proven technology that is expected to save around 3 million gallons of fresh water per year at the Bank of America Tower, enough to meet the yearly needs of 35 households ${ }^{7,8,10}$.

The utilization of this non-industrial waste water from domestic processes is called the Grey Water System. Due to recycling of clean water and the building's many waterconserving devices, the Bank of America Tower will avoid the use of around 10.3 million

Proceedings of 2009 ASEE Gulf-Southwest Annual Conference Baylor University

Copyright (02009, American Society for Engineering Education 


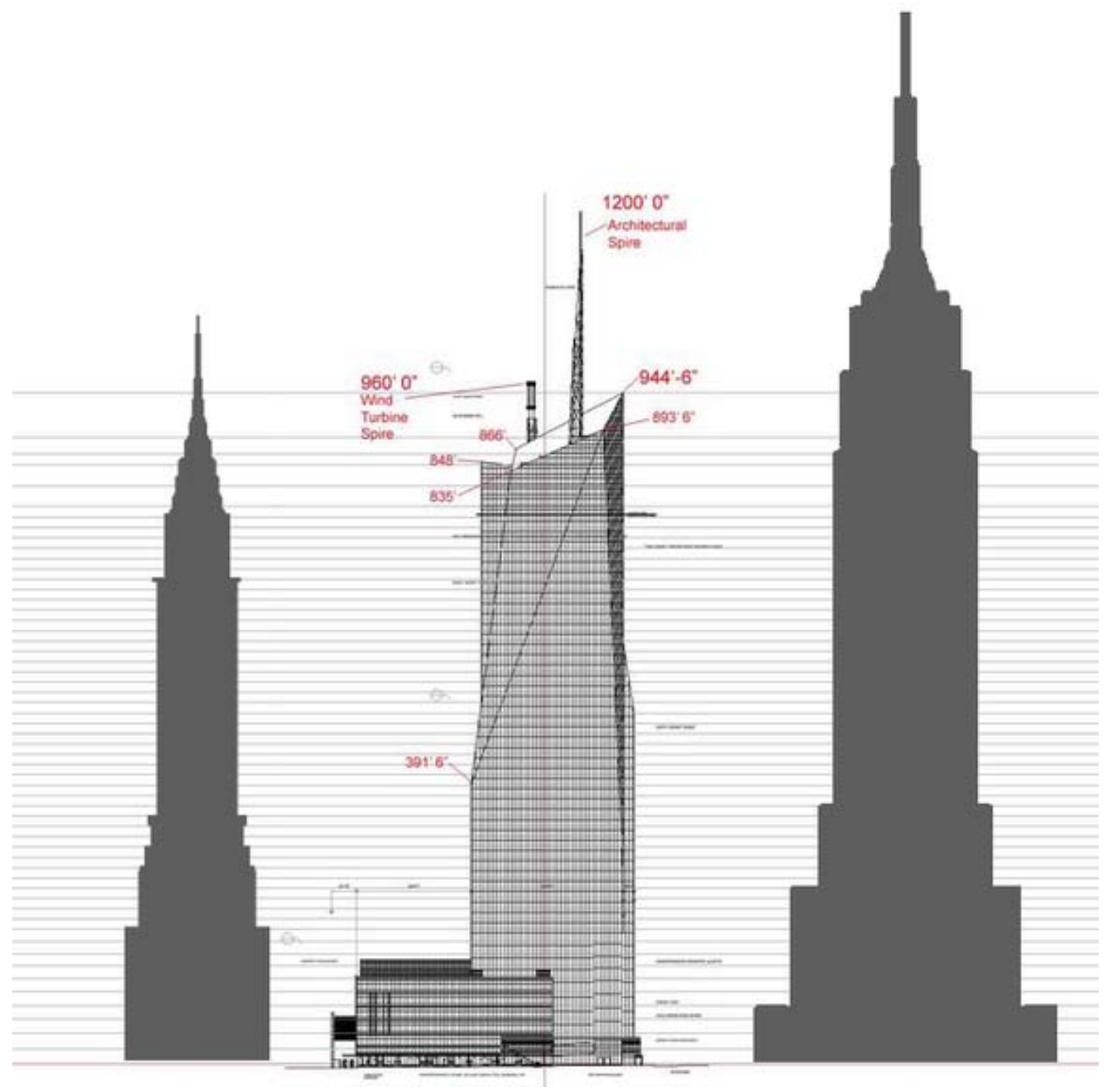

Figure 2.

A demonstration of the height of the Bank of America Tower, New York City when compared to the tallest two buildings in New York City ${ }^{1}$. 
gallons per year. That's enough fresh water to meet the annual needs of 125 households ${ }^{7,8,10}$.

\section{a. Energy Systems}

Mechanical and electrical engineers Jaros, Baum \& Bolles, of New York City, played an important role in the design of water and energy saving systems, which will also include a thermal storage system, waterless urinals, and possibly an anaerobic digester to convert food waste into electricity ${ }^{7,10}$.

Bank of America Tower will eke out huge energy savings by making most of its own electricity. In the tower's podium level, a super-efficient 5.1-megawatt power plant, running on clean-burning natural gas, nearly triples the tower's overall energy efficiency. By reusing waste heat and eliminating losses caused when electricity is shipped via power lines over long distances, the turbine can meet up to four-fifths of the tower's peak needs. The setup wastes just $23 \%$ of the energy from the original fuel used to make the electricity, far better than the $70 \%$ lost at a conventional grid-connected building ${ }^{7,10}$.

One of the biggest challenges in designing green buildings is an effective cooling system. The building features a cooling system which will produce and store ice during off-peak hours and then use ice phase transition to help cool the building during peak load, similar to ice batteries ${ }^{7,10}$.

Bank of America Tower will make ice at night, when power prices are lower, and use it during the day to chill the $\mathrm{A} / \mathrm{C}$ system. In one of the tower's sub-basements there are 44 squat cylindrical ice tanks - 10 feet tall and 10 feet across. These promise to help cut-by $50 \%$ - the amount of power the building needs to cool itself during the hottest days when electricity demand is greatest ${ }^{7,10}$.

Made by CALMAC Manufacturing, the system takes a big bite out of pollution too. On hot summer afternoons, when power demand spikes, utilities typically fire up their least efficient and most pollution-spewing generators. During these peak periods, $90 \%$ of smog-forming particulates are emitted by just $50 \%$ of power plants. Since the building won't need to draw on this dirty power, the building's ice tanks will help to cut out a disproportionate share of pollution. Depending on summertime heat, ice storage systems can pay for themselves in three to five years ${ }^{7,10}$.

Onsite power generation reduces significant electrical transmission losses that are typical of central power production plants . $^{7,10}$.

\section{b. Interiors}


The feeling that you think better in the fresh air and bright sun-at a beach or in the mountains-is genuine. In studies, students' test scores spike by $16 \%$ in naturally lit environments. Office workers see similar productivity gains in naturally lit spaces ${ }^{9}$.

\section{Air Systems}

The building has a giant air filtration plant on the 53rd floor. Air will enter the building only from the top and be cleaned of its impurities. Half of the air will be circulated in the building in a spiral manner and the rest will be ejected out for the city use, making the tower a giant air filter for Midtown Manhattan ${ }^{10}$.

Fewer stories mean more space for mechanical systems between the floors. The building's under floor air distribution system designed to maximize efficiency and to give occupants more control over airflow, demanded that the structural floor to floor heights reach a minimum of $14.5 \mathrm{ft}(4.4 \mathrm{~m})$, more than $1 \mathrm{ft}(0.3 \mathrm{~m})$ higher than in a typical office building ${ }^{10}$.

Clean, oxygen-rich air delivers big productivity gains too. The Bank of America Tower draws in air 10 floors up or higher-far above the stew of tailpipe emissions. Filters catch $95 \%$ of particulate matter, allergens, ozone, and other compounds that can cause illness. Oxygen sensors trigger injections of fresh air into crowded spaces to help prevent "meeting room coma." The tower acts like a 55-story air purifier; when used air is vented back outside, it's still cleaner than the street air ${ }^{10}$.

Heat rises. It's a basic force of nature. Yet most buildings fight this dynamic by pumping chilled air into offices from overhead ducts and then extracting warm air via another set of ceiling vents. It's an inherently inefficient setup requiring that air be over chilled and pressurized to ensure that it flows deeply into every room. The Bank of America Tower does away with overhead chilled-air ducts entirely ${ }^{10}$.

Cool air is pumped into a void below the building's raised floors. As workers and office equipment warm the ambient air in their workspace, the heated air rises to exhaust vents. This in turn pulls chilled air up from below. Since it's not under pressure, the air can be cooled to just $65^{\circ} \mathrm{F}$, rather than $55^{\circ} \mathrm{F}$ in a conventional system. And by eliminating miles of chilled, moist ductwork - where pathogens often exist-this passive system improves overall building health ${ }^{10}$.

\section{Insulation \& lighting}

The tower has floor-to-ceiling insulation glass which restricts heat and maximizes natural light and an automatic daylight dimming system. Further, the building is designed in such a manner that no dark corners are left in it ${ }^{10}$.

Windows are 9.5-feet-tall, from floor-to-ceiling made of "low iron” glass, manufactured 
by PPG Industries and fabricated into windows by Italy's Permasteellisa. They are at once more transparent than conventional glass yet still highly insulating ${ }^{10}$.

Transparent walls separating work areas help exterior light flood deeply into the floor plan and give most workers some view of daylight. Ceiling-mounted photo and motion sensors continually adjust overhead lights, turning them down when natural light is bright or when rooms are empty. The system helps the building cut its demand for electric lighting by $25 \%{ }^{10}$.

\section{c. Exterior}

The glass panels used in the facade has a light dotted pattern printed on them, invisible to the naked eye from a distance, which restricts the infra-red heat radiations of sun while allowing visible light to enter, thus cutting daytime lighting expenses ${ }^{9,10}$.

The exterior wall of the tower will be a clear glass curtain-wall, to complement the building's faceted crystal design. The building's form is sculpted to provide a southfacing surface to address its prominent relationship to, Bryant Park and permit views into and out of the structure ${ }^{9,10}$.

\section{d. Materials Used for Construction}

The building is made largely of recycled material. Care has been taken that almost all

of the material is bought from within a $80 \mathrm{~km}$ range to cut the material transportation costs. Further all the steel used here is recycled from scrap metal, which is molten and removed of its impurities and then cast into giant steel columns. Also the Bank of America tower is constructed using a concrete mix containing slag, a byproduct of steel blast furnaces. The mixture used in the tower concrete contains 55\% cement and $45 \%$ slag. The use of slag cement reduces damage to the environment by decreasing the amount of cement needed for the building, which in turn lowers the amount of carbon dioxide (green house gas) produced through normal cement manufacturing as well as imparts more strength to the concrete columns. The Bank of America Tower alone prevented 53 million tones of $\mathrm{CO}_{2}$ form ejecting out into the atmosphere ${ }^{4,7}$.

\section{e. Parking Facility}

In gridlocked New York City, where parking spaces can rent for $\$ 700$ per month, a project of this scale would typically include hundreds of basement parking spots. At the Bank of America Tower, there are virtually none. Instead, co-developers Durst and Bank of America took the unheard of step of ruling out car access since most employees are likely to rely on regional and city trains. Indeed, subways are often the fastest way into 
and around Manhattan during rush hour. Underground trains get the equivalent of up to 540 miles per gallon ${ }^{2,3}$.

The tower enhances midtown's high-density public transportation network. New pedestrian tunnels connect the building to more subway lines than any other station in New York City. For trips that require a car, the Bank of America relies on an OZO car, New York's first hybrid-only fleet of liveries. Bicycling is also an option. The tower will have secure bike storage and shower access even for nonmembers of the building's health $\operatorname{club}^{2,3}$.

\section{Leadership in Economic and Environmental Design (LEED)}

LEED certification is recognized as standard for measuring building sustainability. It is developed and administrated by the U.S. Green Building Counsel (USGBC). USGBC's mission is to transform the way buildings and communities are designed, built, and operated, enabling an environmentally and socially responsible, healthy, and prosperous environment that improves the quality of life ${ }^{2,3}$.

The LEED is a third party certification program and the nationally accepted benchmark for the design, construction and operation of high performance green buildings. LEED addresses all building types and emphasizes state-of-the-art strategies for sustainable site development, water savings, energy efficiency, materials, resource selection, and indoor environmental quality. LEED is a practical rating tool for green building design and construction that provides immediate and measurable results for building owners and occupants ${ }^{2,3}$.

\section{Summary and Conclusions}

The Bank of America Tower stands as a pioneering model for modern construction by implementing innovative environmental friendly features ${ }^{1,2,3,4,6}$. It stands as an inspiration for future construction of Green Buildings ${ }^{2,3,6}$ and makes cities a better place in which to live.

It is designed as the world's most environmentally responsible ${ }^{2,3,6,10}$ high-rise office building, focusing on:

- Sustainable sites, water efficiency, indoor environmental quality, energy and atmosphere ${ }^{5,7,8}$

- Being the first high-rise to strive for U.S. Green Building Council’s Leadership in Energy \& Environmental Design "Platinum" designation ${ }^{2,3,5,9,10}$

Proceedings of 2009 ASEE Gulf-Southwest Annual Conference

Baylor University

Copyright (02009, American Society for Engineering Education 
- Reducing energy consumption by $50 \% \%^{7,10}$

- Reducing potable water consumption by $50 \%^{7,10}$

- Contributing zero storm water to city wastewater system ${ }^{8}$

- Utilizing a minimum of $50 \%$ recycled material in building construction ${ }^{7}$

- Obtaining a minimum of $50 \%$ of building material within 500 miles of site ${ }^{7,10}$

\section{References}

1. http://en.wikipedia.org/wiki/Bank_of_America_Tower\%2C_New_York_City[Introduction, about Bank of America Tower, Accessed in July, 2008]

2. http://www.durst.org/_1bp_news.asp[A bout Bank of America Tower, Accessed in July, 2008]

3. http://newsroom.bankofamerica.com/index.php?s=press_releases\&item=4405 [Bank of America Tower, Accessed in July, 2008]

4. http://www.us-concrete.com/news/features.asp[Green Features, Accessed in July, 2008]

5. http://www.skyscraper.org/EXHIBITIONS/GREEN_TOWERS/gt_boa.htm [Materials used, Accessed in July, 2008]

6. http://www.thegbi.org/home.asp [Green Features, Accessed in July, 2008]

7. http://www.un.org/docs/ecosoc/meetings/2005/docs/Cook.pdf [Sustainable Features, Accessed in July, 2008]

8. http://www.pacinst.org/resources/water_to_air_models/ [Water to Air models, Accessed in July, 2008]

9. Civil Engineering News - October 2004 [Height of the building, Interiors \& Energy]

10. http://images.businessweek.com/ss/07/02/0228_greenbuilding/source/1.htm [Sustainable Green Features, Accessed in July, 2008]

ARVIND KRISHNA GUDURI

Arvind is currently pursuing his Master of Engineering degree at Lamar University. Arvind worked as a Site Engineer with N.V.M Seeta Ramanjaneya Constructions, where he assisted in calculations related to structures, verification of design codes and specifications.

BHARATH DEVINENI

Bharath is a Graduate Civil Engineer from Lamar University. He is currently working with Amani Engineering Inc. as a Surveying Engineer. His duties include leading five survey members, Auto CAD drafting, assigning work, checking survey, inventory, and planning. Bharath is a registered Engineer in Training.

\section{RAMAKRISHNA MANCHIKATLA}

Ramakrishna is a Graduate Civil Engineer from Lamar University. He is currently working with Kyur Kendall Associate's Inc. as a Structural Engineer. His duties include Design and Analysis of Structures. Ramakrishna is a registered Engineer in Training.

\section{ENNO KOEHN}

Enno "Ed” Koehn is Professor of Civil Engineering at Lamar University. Dr. Koehn has served as the principle

Proceedings of 2009 ASEE Gulf-Southwest Annual Conference

Baylor University

Copyright (C2009, American Society for Engineering Education 
investigator for several research and development projects dealing with various aspects of construction. He also has experience in the design, scheduling, and estimating of facilities. He has authored/co-authored over 200 papers in engineering education, as well as the general areas of civil and construction engineering. Dr. Koehn is a member of ASEE, AACE International, ASCE, NSPE, Chi Epsilon, Tau Beta Pi, Sigma Xi, and is a registered Professional Engineer and Surveyor. 